\title{
THE ROLE OF THE CRIMINAL LAW IN REDEFINING 'YOUTH' IN MID-NINETEENTH-CENTURY UPPER CANADA
}

\author{
Susan E. Houston
}

Why Grace Marks, a sixteen-year-old Irish servant found guilty of the brutal murder of her employer, had her death sentence commuted in 1843, and James Fleming, a seventeen-and-a-half-year-old unemployed Irish telegraph operator, was hanged in 1858 for the murder of a young drinking companion, lies near the centre of the problem.' 'Youthfulness,' defined chronologically, they shared, along with an Irish immigrant working-class background and the vulnerability that that entailed when it came to dealing with the criminal justice system. But their experiences of 'youth'-as one of the successive stages in the process of growing up-differed as markedly as did the meanings which contemporaries gave to their circumstances.

Over the past decade or more, historians have come to appreciate how historically contingent have been the economies, structures, and intergenerational relationships of the families in which the experience of growing up is imbedded. Moreover, the delimiting quartet of gender, social class, ethnicity, and race, here as elsewhere, have incessantly cross-cut and refashioned the basic components of maturation into multiple forms. Nevertheless, over the course of a century or more, from the late eighteenth to the early twentieth century in Anglo-American societies, the cultural importance of the age-defined experience of 'youth' altered dramatically. Perhaps because the process of transformation was a protracted and ragged affair, the business of youth-invariably punctuated by conflicting responsibilities and competing ambitions-was an anxious time for young people, their families, and political authorities more generally. It was the unsettledness which was so worrying: as Harvey Graff recently expressed it, 'Notions of the "normal" were still in construction."

1. A York University Faculty of Arts Leave Fellowship (1987-88) and The Osgoode Society Fellowship in Legal History (1991-92) have supported the larger project on nineteenth-century juvenile justice from which this paper derives.

2. Harvey J. Graff, 'Remaking Growing Up: Nineteenth-Century America,' Histoire sociale/Social History 47 (Mai-May 1991): 45. Graff's footnotes, 35-59, provide an excellent guide to the recent literature. 
Age and gender have also come to the fore in recent cultural analyses of nineteenth-century criminal procedure, punishment, and penal reform. ${ }^{3}$ John Beattie's important observation that changes in the institutional roles and rules of the law - and, by extension, notions of criminality - can only be understood in relation to other aspects of criminal administration has been extended to encompass the total society and culture in which the changes were embedded. ${ }^{4}$ The essential relationship is captured, in my view, in David Garland's formulation: 'Penal practices exist within a specific penal culture which is itself supported and made meaningful by wider cultural forms, these in turn, being grounded in society's patterns of material life and social action. 5 . Cultural assumptions about the characteristics of young persons, especially notions of femininity and masculinity adhering to images of youth, influenced the ways in which youthful criminal behaviour was-quite literally-seen. From the initial perception of a 'crime' and the teasing out of its essential features to the adjudication of the case, the sex of the offender determined differing outcomes. ${ }^{6}$

In the first half of the nineteenth century in the English-speaking communities of British North America, the crime of murder was relatively uncommon. Youthful 'killers' were exotic. While the circumstances of any murder case are exceptional, murder draws attention to itself. Murder trials in Upper Canada were, by mid-century, widely reported in city and small-town newspapers, while the scaffold spectacle in its infrequency could attract ten thousand curious onlookers. It is precisely because each of these two cases of youthful murder caused a sensation that I focus on them. In proposing to explore the role of the 'Law,' I take the term in its broadest sense: not only criminal legislation, judicial procedure, and penal sanctions, but the wider discussion-of crime, criminal character, guilt, evidence, and due process — which these crimes triggered. To anticipate my argument: it is in the presence-and absence-of multiple voices in the discussion that one can glimpse the outline of the shifting and gendered identities of youth.

For more than a generation, in the elongated ribbon of lake-front settlement running westward from the Ottawa River known as Upper Canada, the administration of criminal justice appears to have been relatively spare in its procedures and pragmatic in its judgement. Wildly unsuitable in ways unique to each colonial society, unreformed English law, with its extravagant reliance on capital

3. See esp. Martin J. Wiener, Reconstructing the Criminal: Culture, Law and Policy in England, 1830-1914 (Cambridge: Cambridge University Press, 1990); Lucia Zedner, Women, Crime and Custody in Victorian England (Oxford: Clarendon Press, 1991); and David Garland, Punishment and Modern Society: A Study in Social Theory (Oxford: Clarendon Press, 1990).

4. John Beattie, Crime and the Courts in England, 1660-1899 (Oxford: Clarendon Press, 1986), 621.

5. Garland, Punishment and Modern Society, 211.

6. Zedner, Women, Crime and Custody, 2. 
offences, was 'received' and only mildly tempered (tampered with) by early colonial statutes. By the mid-1820s, Upper Canada, the destination of the preponderance of British emigrants after the Napoleonic wars, was the fastest growing English-speaking colony, but only in 1833 adopted a local criminal code which dramatically limited the number of capital offences. ${ }^{7}$ In practice, rules invariably bent to necessity.

While the sheer numbers of persons involved in the assize court proceedings made them notable occasions, only the barest echo of the intimidating, legitimating, ritual of an English criminal assizes survived the transatlantic passage. ${ }^{8}$ But if there was little of the 'majesty' which Douglas Hay has argued was an essential strand of the ideological authority of late eighteenth-century English criminal procedure, 'justice' and 'mercy' operated at various levels. Juries often failed to convict, in more serious cases, or made recommendations for mercy which the assize justices endorsed. After a guilty verdict and sentencing, the stage of petitioning began. Family, friends, neighbours, and other parties-frequently grand jurors and magistrates - interested in some particular aspect of the case would petition the colonial executive for a stay of execution, commutation of the sentence to a prison term or banishment, or occasionally for a pardon. ${ }^{9}$ The process was often lengthy, the outcome unpredictable and infrequently in favour of the accused. Nevertheless, the paper trail of grand jury recommendations, judges' formal reports, and petitions-signed in some cases by hundreds of citizens, male and female - ensured the appearance of justice necessary to deflect an impression that the exercise of executive prerogative was tantamount to arbitrary power wielded without consideration of the popular will.

7. For a valuable analysis of the impact which late eighteenth-century English penal reform had in Lower Canada, see Jean-Marie Fecteau, 'Régulation sociale et répression de la deviance au Bas-Canada au tournant du 19e siècle (1791-1815), Revue d'histoire de l'Amérique française 38 (printemps 1985): 499-521. For necessary background, see especially Jim Phillips, 'The History of Canadian Criminal Justice 1750-1920,' in Criminology: A Reader's Guide, ed. Jane Gladstone et al. (Toronto: University of Toronto Centre of Criminology, 1991), 65-124; esp. 68-69. Unfortunately D. Owen Carrigan, Crime and Punishment in Canada: A History (Toronto: McClelland \& Stewart, 1991) offers little more than a pastiche of poorly digested data from incompatible sources.

8. Douglas Hay, 'Property, Authority and the Criminal Law,' in Albion's Fatal Tree: Crime and Society in Eighteenth-Century England, ed. Douglas Hay et al. (London: Penguin, 1975), 17-63.

9. John Weaver, 'Crime, Public Order, and Repression: The Gore District in Upheaval, 1832-1851, 'Lawful Authority: Readings on the History of Criminal Justice in Canada, ed. R.C. Macleod (Toronto: Copp Clark Pitman, 1988), 22-48, esp. 45. See also the various biographies of early nineteenth-century murderers collected in Provincial Justice: Upper Canadian Legal Portraits from the Dictionary of Canadian Biography, ed. Robert Fraser (Toronto: The Osgoode Society, 1992). 
Petitions played an especially prominent part in cases involving youthful defendants - who comprised a modest cohort amongst the still relatively few capital cases which dotted the assize calendars through to the 1830s. 'Youthfulness' had had a time-honoured claim to benefit from judicial discretion and-in Upper Canada - from the 1790s onward could provide the extenuating circumstance necessary to secure pardons, banishment and, latterly, penitentiary terms in cases of capital crimes perpetrated by young males and young females. ${ }^{10}$

While the small number of cases is idiosyncratic and the surviving documentation varies widely in its completeness (in some cases the final disposition is unclear), nonetheless sharply gendered social expectations shaped the arguments for clemency. Lack of education, slowness of wit (frequently characterized as bordering on imbecility), general vulnerability to suggestion and to panic: this was the typical arsenal of defence for young women, be it a case of infanticide, arson, or murder. ${ }^{11}$ On the other hand, 'family fortunes' in one way or another provided a common thread to appeals on behalf of young males, especially in the early years. William Newberry, 'but 20 years of age,' was convicted on 8 August 1800 in Niagara of the capital crime of highway robbery and, after successful petitions and a sympathetic judge's report, was banished for life. Newberry's case was not promising: the presiding judge, William Dummer Powell, considered the prisoner to be 'a young man of bad character' and the charge to be a cover for attempted rape, for which the testimony of the victim/witness, Jane Lambert, would have secured a conviction. Nevertheless, Powell concluded that 'his depravity and want of proper Education is attributed to the early loss of his father, who was a loyalist executed by the Rebels for bearing arms in the Royal Cause.' Not surprisingly, the petitioner on behalf of the convicted youth's widowed mother echoed the themes of parental loss and loyalty to the Crown: the Executive Council concurred in Powell's view that there was no case for proceeding to execution on the grounds of an exemplary punishment. ${ }^{12}$ Philip Pier's

10. For late eighteenth- and early nineteenth-century English practice, see Beattie, Crime and the Courts in England, 443; Peter J.R. King, 'Crime, Law and Society in Essex, 1740-1820' (Ph.D. diss., Cambridge University, 1984), 368-72; Wiener, Reconstructing the Criminal, esp. 17-20. For Upper Canada, see especially Charles K. Talbot, Justice in Early Ontario, 1791-1840: A Study of Crime, Courts and Prisons in Upper Canada with a description of 1,300 original unpublished letters located in Public Archives of Canada (Upper Canada Sundries) and pertaining to the criminal justice system of Upper Canada (Ottawa: Crimcare, 1983).

11. Cf. Angelique Pilotte, fl. 1815-1818, Dictionary of Canadian Biography [D.C.B.], IV: 672-74, reprinted in Fraser, Provincial Justice, 327-31; case discussed in Constance Backhouse, Petticoats \& Prejudice: Women and Law in Nineteenth-Century Canada (Toronto: The Osgoode Society, 1991), 112ff. Grace Smith, 1839, National Archives of Canada [NA], RG 5, B3, vol. 10, 1341-49; RG 1, E3, vol. 86, 14-27; also Jonas Jones, $D C B$, VII: 60 . For Grace Marks, see below.

12. NA, RG 5, A1, Upper Canada Sundries, mfm C4502, pp. 447-51, 474; RG 68, Upper 
father made a different appeal to family in defence of his fourteen-year-old son convicted of setting fire to a barn. The boy's execution would 'blast the reputation of his family in the eyes of the community and decend [sic] to his posterity, and not to be forgotten by an unforgiving and vindictive world,' the father pleaded, as much for himself as for the boy. ${ }^{13}$

By the 1820s a distinctive note of uneasiness entered public discussion of crime and punishment among the Upper Canadian elite. The critique of the system of criminal punishments being mounted in England and the accompanying agitation for prison reform were transported to all the English colonies of British North America. ${ }^{14}$ In Upper Canada, recognition of the material inadequacies of local gaols and correspondingly the absence of appropriate means of effective punishment secured support for a provincial penitentiary where prisoners less experienced in crime could be 'reformed' and hard labour could be ensured. ${ }^{15}$ The knowledge and interests of local magistrates, members of grand juries, pioneer public servants, and others familiar with the courts and the administration of criminal justice in effect framed the colonial debate. But the voice from the high court was the key element. Through the assize ritual of the Address to the grand jury and the grand jury's Presentment in reply, minor variations in the court's calendar were increasingly reinterpreted as evidence of social disorder.

Experience over the years on the assize circuit apparently fuelled the Chief Justice's anxieties about the direction society seemed to be taking. At the same time, his perambulations gave him a singular opportunity to educate the citizenry, notably through newspaper reporting, to the notion that crime spoke to the very character of society. ${ }^{16}$ John Beverley Robinson, the Chief Justice, was a Loyalist and governors' intimate who has been characterized by textbook writers as an unregenerate 'high church tory.' The caricature inevitably captures something, but not all, of its subject. To his credit, as a jurist Robinson's oft-stated

Canada Register B, pp. 181-82; 'William Dummer Powell,' $D C B$, VI: 605-13.

13. NA, RG 5, B3, vol. 7, Petitions and Addresses, 439-41: Petition of Philip Pier of the Township of Toronto, yeoman, to H.E. Sir Peregrine Maitland, n.d.

14. Phillips, 'The History of Canadian Criminal Justice,' 70-71.

15. John Beattie, Attitudes Towards Crime and Punishment in Upper Canada, 18301850: A Documentary Study (Toronto: University of Toronto Centre of Criminology, 1977), 1-25, 37-40; 'Report of Select Committee on Expediency of Erecting a Penitentiary,' Journal of the House of Assembly of Upper Canada, 1831, 211-12; 'Message from His Excellency with Despatch on the Subject of Prison Discipline,' ibid., 1836, no. 4.

16. Robert L. Fraser "“Like Eden in Her Summer Dress": Gentry, Economy and Society: Upper Canada 1812-1840' (Ph.D. diss., University of Toronto, 1979), 244, 343; Patrick Brode, 'Grand Jury Addresses of the Early Canadian Judges in an Age of Reform,' Law Society Gazette 23 (1989): 134-36; also Donald J. McMahon, 'Law and Public Authority: Sir John Beverley Robinson and the Purposes of the Criminal Law,' University of Toronto Faculty of Law Review 46 (Spring 1988): 390-423. 
convictions about the essential moralizing, reforming role of the criminal law, as it related to public character, did not hold universally. Yet the message, however qualified, was clearly and repeatedly stated. 'The formation of the moral character of a people must of necessity be gradual,' he cautioned the grand jurors in Ottawa, ${ }^{17}$ but fostering that process of public character building was, for Robinson, the primary role of the criminal justice system.

Through the $1830 \mathrm{~s}$, a common discourse distinguished discussions of social policy, whether the issue was lunacy, poverty, criminality, or ignorance, which centred on the issue of individual moral character and its relation to a broader notion of social morality. Significantly, neither the Tory elite nor political reformers monopolized the 'high ground' in these debates. ${ }^{18}$ From this new moralistic perspective, however, the relative absence of serious crime no longer occasioned congratulations. Petty crimes, committed by youthful-if not downright juvenile - offenders irritated the court but, more importantly, were projected, rhetorically, as an omen of disorder and loss of control. 'The vices of drunkenness and gambling, the profanation of the Sabbath, and the frequent congregation of idle persons, apprentices and others, at places of public amusement are the sources of most crimes,' Chief Justice Robinson fulminated in Toronto in 1834, convinced that 'it is at these wretched resorts of the idle and disorderly that young men of all conditions in Society often lay the foundation of lasting misery and disgrace. 19

Fear of an urban 'under class,' which the increasing volume of public discussion of moral disorder signalled, was rooted in a particular class view of orderly social relations. ${ }^{20}$ Moreover, anxieties triggered by unstable and shifting social relations within families relating to gender and age also found expression in criminal proceedings. Chief Justice Robinson's discomfort at having to hear a case of wife abuse at the Niagara assizes in 1829, one senses, was ideological as well as professional. 'It was formerly held that moderate correction by the husband must be permitted-That idea seems to be now disclaimed, but nevertheless while it is right that Courts of Justice should restrain and punish violence on the part of the husband it is not fit that their time should be taken up by the notice of...squabbles between husbands and their wives,' he noted to himself. ${ }^{21}$

17. Archives of Ontario [AO], MU 5907, 'J.B. Robinson Papers: Charges to the Grand Jury, 1829-1841,' Ottawa, 19 Sept. 1837.

18. For a broad analysis of the defining role of the 'discourse of character' in early Victorian penal reform, see Wiener, Reconstructing the Criminal, 38-45.

19. Address to the Grand Jury, Colonial Advocate, 10 Apr. 1834. See also Russell Charles Smandych, 'The Upper Canadian Experience with Pre-Segregative Control' (Ph.D. diss., University of Toronto, 1989), 362.

20. Cf. Beattie, Attitudes to Crime and Punishment; Susan E. Houston, 'Victorian Origins of Juvenile Delinquency: A Canadian Experience,' History of Education Quarterly XII (Fall 1973): 254-80.

21. AO, MU 5907, 'J.B. Robinson Papers: Charges to the Grand Jury,' 1829, Niagara. 
By the 1830s anxieties about gender relations were increasingly being felt and voiced by males of the elite and middling classes: family violence was but one of its modes of expression. 22

Evidence of the malicious influence which a parent could exert over a young girl was invariably deplored by the justices, yet their reasoning hinged on conventional assumptions about the malleable character and inherent vulnerability of young females. Young males, on the other hand, were deemed to have formed a character by a fairly young age. Certainly, Mr. Justice Jones spotted thirteen-year-old William White as 'exceedingly intelligent but undoubtedly a very bad boy' as he sentenced him in 1840 to two years in Kingston Penitentiary for stealing $£ 10$ from his employer. ${ }^{23}$ When child-parent relations were strained, it was increasing seen as the result of youthful male rebellion, not unreasonable parental discipline. Moreover, by the 1830 s many rural inhabitants could read (and relish) the consequences of youthful rebellion in the pages of the growing number of local town newspapers which 'copied' the lengthy coverage of capital crimes from the city press. ${ }^{24}$ The genre of criminal life stories, which began local publication in Kingston in 1830 with the case of William Kain, provided a still wider audience than the local newspaper for the ritual gallows address. The formula for both was straightforward: the details of the crime were sensationalized, grounded more firmly in local community fears than observed fact. The culprit's career invariably began in youthful disobedience: falling into bad company, novel reading, and drinking ensued until he was caught in a downward spiral leading inevitably to the gallows. The moral fit perfectly with the now pervasive rhetoric preaching the necessity for restraint, lest small vices left unchecked lead one, in Kain's words, 'headlong to destruction., 25

22. Cf. Cecilia Morgan, 'Gender, The Family and Religion in Upper Canada, 18291840 ,' paper given at the Canadian Historical Association annual meeting, Charlottetown 1992; Susan E. Houston and Alison Prentice, Schooling and Scholars in Nineteenth-Century Ontario (Toronto: University of Toronto Press, 1988), 102.

23. Cf. Jonas Jones, DCB, VII: 460, re Eliza Mott; NA, RG 5, A1, Upper Canada Sundries, 1840, 29 May: Mr. Justice J. Jones, general report on the Eastern Circuit Spring Assizes (mfm C6913, pp. 132998-133003), Midland District, Elizabeth Water.

24. In 'Myths in Some Nineteenth-Century Ontario Newspapers,' in Aspects of Nineteenth-Century Ontario, ed. F.H. Armstrong et al. (Toronto: University of Toronto Press, 1974), 253-66, James Reaney identifies a tension within 'polite society'; although seemingly "ranged against "levity" and "indecency" it is actually more than interested in them,' 262.

25. The Life of William Kain, who was executed at Kingston, Upper Canada, on the 6th day of September 1930, for the murder of John Rodolph Couche (Kingston: The Herald Office, 1830). For a discussion of the press and pamphlet coverage of Upper Canadian capital trials, see John Choules, 'The Periodic Necessity of Example: Deterrence and the Dramaturgy of Public Executions in Ontario, 1792-1869' (Major 
Certainly in the early Victorian decades, the public moralization of youthful character was almost entirely oriented towards males. The mere fact that as late as 1851 almost forty-five percent of the colony's population was under the age of sixteen years accounts for some of the concern. Halving that figure still leaves a highly visible population which, from childhood on, enjoyed an almost boundless range for acts of mischief. Generation, more than social class, brought the lads together to disnupt religious revivals, join in charivaris, or prowl the streets of Kingston in 'midnight frolics.' As villages became towns and towns cities, the informal recreation of the local tavern had competition in the local theatre or fire company. ${ }^{26}$ As Chief Justice Robinson understood, in this early- to mid-Victorian colonial society, stereotyping labels such as 'rough,' 'rowdy,' or 'respectable' capture the flavour of the masculine cultures of different age groups (and one must add ethnic groups) more accurately than those of class-and neither very well. In the 'discourse of character' which dominated public discussion of social policy, male 'youth' was characterized as a prolonged, exhilarating, and determining contest between responsibility and distraction, promise and temptation. The publicness of male activity — work, leisure, or simply being —undoubtedly helped make the outcome of the contest 'public' business.

A young female 'in public' was anomalous; as a consequence she was an object of either charity or censure. The latter was fairly infrequent: prostitutes were not particularly young and the female youngsters who ended up in gaol were often in the care of their convicted mothers. The polarities embedded in early Victorian constructions of femininity left little room for the court to manoeuvre. Toronto Magistrate George Gurnett flatly refused to sentence a local servant girl

Research Paper, History Department, York University); also comments in two biographies: Cornelius Burley, DCB, VI: 93; Charles French, ibid., 265-66. Also, Peter King, ibid., 139-40; J.A. Sharpe, "'Last Dying Speeches": Religion, Ideology and Public Executions in 17th Century England, Past \& Present 107 (1985): 144-67; Michael Harris, 'Trials and Criminal Biographies: A Case Study of Distribution,' in The Sale and Distribution of Books from 1700, ed. Michael Harris and Robin Myers (Oxford: Oxford Polytechnic Press, 1982), 1-36.

26. Patrick Shirreff, A Tour Through North America; Together with a Comprehensive View of the Canadas and United States as Adapted for Agricultural Emigration (Edinburgh: Oliver and Boyd, 1835), 183ff.; Bry an D. Palmer, 'Discordant Music: Charivaris and Whitecapping in Nineteenth-Century North America,' Labour/Le Travailleur 3 (1978): 5-62; W. Thomas Matthews, 'The Myth of the Peaceable Kingdom: Upper Canadian Society in the Early Victorian Period,' Queen's Quarterly 94 (1987): 391, and 'By and For the Large Propertied Interests: The Dynamics of Local Government in Six Upper Canadian Towns during the Era of Commercial Capitalism' (Ph.D. diss., McMaster University, 1985), 184-86; Richard Reid, ed., The Upper Ottawa Valley to 1855: A Collection of Documents, Ontario Series XIV (Toronto: The Champlain Society, 1990), Doc. B14, Perth Theatre, 1830; Charles French, $D C B$, VI: 265-66. 
sued by her master to the Toronto Gaol in 1839 on the grounds of its contaminating effect. The gaol, he wrote, was 'filled with women of the most abandoned and loathsome character, and I felt great reluctance at the idea of exposing this young girl to the contamination of such society which would probably prevent her from getting a respectable situation afterwards, and might ruin her future prospects in life. 27

At about this time Grace Marks arrived in Toronto, having emigrated with her Irish Protestant father. ${ }^{28}$ Grace, aged twelve, engaged as a servant in a succession of taverns in the east end of the city while her father, a stone-mason by trade, she thought settled in Toronto Township, twenty miles to the west. Early in July, 1843, Grace was engaged by Nancy Montgomery, housekeeper to Thomas Kinnear, a Scottish gentleman who lived off Yonge Street on the outskirts of the village of Richmond Hill, sixteen miles north of Toronto. Within the month, during the day of Saturday, July 30, Grace and a fellow servant, James McDermott, a twenty-year-old Irish Catholic, conspired to murder both the housekeeper and Kinnear. After clumsily concealing the bodies (the housekeeper's body was found in the wine cellar doubled-up under a barrel, with the legs protruding), the pair set out in Kinnear's wagon for Toronto with various of the belongings of the deceased. They caught the early morning steamer crossing Lake Ontario to Lewiston, New York, where, after an unorthodox and dramatic pursuit organized by a friend of Kinnear's, they were arrested in a waterfront tavern in the early hours of Monday morning. They were returned to Toronto to face a coroner's inquest, where they were indicted for murder. McDermott and Marks were tried separately on November 3 and 4, 1843, on the single count of wilfully murdering Thomas Kinnear. McDermott was found guilty and executed on November 21. In Grace Marks's case, the jury added a recommendation of mercy to their guilty verdict; the executive concurred and her sentence was commuted to life imprisonment in the Provincial Penitentiary.

At the time, the deaths of the well-off unmarried Scottish gentleman and his housekeeper excited enormous interest. A whiff of sexual impropriety added to fascination with the gruesome details of murder. Predictably large numbers crowded the inquest and trials, which were reported at length, with editorial

27. Paul Craven, 'The Law of Master and Servant in Mid-Nineteenth-Century Ontario,' in Essays in the History of Canadian Law, ed. David Flaherty (Toronto: The Osgoode Society, 1981), I: 183 fn 27: NA, RG 5, Al, Upper Canada Sundries, O'Hara to Harrison, 1 Nov. 1839 and enclosures. For an exceptionally fine portrait and analysis of the female worlds of the streets and 'asylums,' see Judith Fingard, The Dark Side of Life in Victorian Halifax (Nova Scotia: Pottersfield Press, 1989).

28. References to the manuscript and published sources used to verify the details of Grace Marks's life are cited in her unpublished biography on file at the offices of the Dictionary of Canadian Biography. A fictionalized account of the Kinnear murder was written by Ronald Hambleton, A Master Killer (Toronto: Green Bushell, 1978). 
comment, not only in the city papers, but across the colony. Competition for news was keen and The Chronicle and Gazette and Kingston Commercial Advertiser almost scooped the Toronto press with a letter from a local resident's son who was the Postmaster at Richmond Hill. ${ }^{29}$ A special edition of the trial proceedings, complete with portraits and confessions, followed hard on the November events. ${ }^{30}$ As the British Colonist (Toronto) observed, 'of our domestic horrors it stands the first upon the list' for it seemed 'a murder more coldblooded and atrocious' had yet to be known in Canada. ${ }^{31}$ A number of elements contributed to the special interest in the case. In a very practical way the crime revealed the severe limitations of law enforcement in the colony: it required the enthusiasm of a local railway promoter, and Kinnear's friend, to overcome official confusion over the appropriate jurisdiction of city and county magistrates. ${ }^{32}$ More disconcerting was the uneasiness aroused by a murder committed by servants seemingly without provocation. Such a crime exposed the vulnerability of decent people to wickedness and violence. Local artist Hoppner Meyer, for example, was quick to appeal to such fears. Seeing the possibility of a popular market for portrait engraving, he publicized the innovations in police detection effected by the mass circulation of portraits of wanted criminals, and urged those "who are in the habit of keeping servants to possess themselves of this little work of art. 33

At the age of twenty years and four months in 1843, James McDermott might well have been a figure deserving of some measure of mercy. As an Irish Catholic 'youth,' he had worked prior to 1840 as a waiter on board steamers plying the Quebec/Montreal route. He enlisted in 1840 , aged about seventeen years, in a Lower Canadian regiment and when it was disbanded, enlisted again as a private and served as servant to Captain Macdonald of the Glengary Light Infantry. On release, in June 1843, he took a position with Thomas Kinnear. But no one showed sympathy for McDermott. From the moment the bodies were discovered, in all the press accounts he was cast as the villain. The trial jury deliberated a

29. Chronicle and Gazette and Kingston Commercial Advertiser, 2 Aug. 1843; copied by the Bytown Gazetter and Ottawa Rideau Advertiser, 10 Aug. 1843. See also Cobourg Star, 9 Aug. 1843; Chatham Weekly Journal, 12 Aug. 1843. By contrast, the well-circulated Methodist paper, the Christian Guardian, gave only a brief account in its 2 Aug. issue.

30. The Trials of James McDermott and Grace Marks at Toronto, Upper Canada, November 3rd and 4th, 1843, for the MURDER of Thomas Kinnear, Esquire, and his housekeeper Nancy Montgomery... (Toronto: Star and Transcript Office, 1843).

31. British Colonist, 9 Aug. 1843, editorial.

32. Journals of the Legislative Assembly, 1850, App. FF; Landmarks of Toronto (Toronto, 1898), I: 105-11; III: 260; British Colonist, 9 Aug. 1843, editorial.

33. Letter to the Editor from 'Justice,' British Colonist, 31 Oct. 1843; see also 9 Aug. 1843 , editorial. 
brief ten minutes in his case before satisfying the overwhelming public/political desire for retribution.

In striking contrast, his co-conspirator, Grace Marks, captured the imagination of the press and (can one assume?) the public. She was presented as alone; neither the presence nor absence of her father or other family members was a matter of comment. Her appearance and what hint it might have given of her state of mind provided the only points of interest. On her first appearance at the opening of the coroner's inquest, she was portayed as possessing 'good features' and as being 'in point of personal appearance much superior to her paramour.' Quickly her love of clothes, a stock failing of Irish servant girls, created a sensation. ${ }^{34}$ A Richmond Hill local pointed out that she was wearing Nancy Montgomery's frock, ribbon under her bonnet, and tippet, and was carrying her parasol-at which point Grace apparently 'sat, or sank down in the chair, in a state of apathy and stupefaction.' The clothes changed but a parasol persisted on the day of her examination, when it was noted that she seemed 'to have been collected enough to make her toilet with care.' Her state of mind was less easily read. The dominant press voice of the British Colonist, having declared confidently at the outset that Grace was 'wholly devoid of education,' reported throughout the inquest that 'her appearance by no means indicated a mind oppressed with grief at the awful situation in which she is placed.'

The defence tactics employed by Kenneth Mackenzie, a respected Kingston barrister, milked rather than modified conventional gender stereotypes. James McDermott's protest that Grace had lured him into doing the murders because she was jealous of Nancy cast her in the role of knowing sexual predator. Grace's defence - that James had terrorized her into being an unwilling accomplice, had actually tried to shoot her (there was some evidence of a bullet lodged in a door-jam) and then promised to marry her-reinforced the easily accepted portrait of the naive, ill-educated, vulnerable female. Neither the crown counsel nor the Chief Justice accepted that characterization; however, one Toronto newspaper, The Mirror, a voice for working-class Irish Catholic immigrants, did. Convinced in August, by the inquest evidence, of the thorough guilt of both parties, The Mirror remained adamantly unsympathetic to fellow Catholic McDermott. By November Grace Marks's case appeared differently. At the trial Alderman Dixon, for whom Grace had worked briefly in Toronto (and the only figure from her past to appear) testified to the effect that she was 'soft' or of 'weak intellect': that evidence combined with other details convinced the paper of her story. The Chief Justice was soundly rebuked for his charge to the jury. In hitherto unreported remarks, The Mirror quoted him as telling Grace: 'If you had

34. Cf Christine Stansell, City of Women: Sex and Class in New York, 1789-1860 (Urbana: University of Illinois Press, 1986), 164; and Mariana Valverde, 'The Love of Finery: Fashion and the Fallen Women in Nineteenth-Century Social Discourse,' Victorian Studies 32 (Winter 1989): 169-88. 
possessed that strength of mind which would have led you to weigh well the advantages and disadvantages of the course you were pursuing you could not have acted as you did. ${ }^{35}$ The Mirror interpreted 'strength of mind' as 'intelligence'-which Grace lacked, it was now convinced. Robinson, on the other hand, given his long preoccupation with the demoralizing tendencies undermining the social order, might well have equated 'mind' with 'character'-a quality young female Irish servants were not thought to possess in quantity. For whatever reason, despite his harsh direction, the jury 'strongly' recommended her to mercy and on the expectation that it would be granted, found her guilty.

Grace Marks began a career as 'the girl murderess' upon entering the Penitentiary. Any hint of individuality which might have been gleaned from the criminal proceedings was quickly overwhelmed by the melodramatic imperatives of the criminal's tale. Susanna Moodie, an internationally published colonial writer, portrayed 'the celebrated murderess' in Life in the Clearings (1853) as a figure deserving of both denunciation and sympathy. In a sensational retelling of the crime, Moodie presents Grace after five years in the penitentiary as a soul tortured by the memory of her crime. Conveniently, Grace's temporary committal to the Provincial Lunatic Asylum provided Moodie with material for a later moralistic chapter in which she finds Grace in the Asylum 'no longer sad and despairing but lighted up with the fire of insanity and glowing with a hideous and fiend-like merriment. 36

Grace Marks's stay in the Lunatic Asylum was brief-and in all likelihood unnecessary, in that the Asylum superintendent suspected that the insanity of most of the twelve penitentiary prisoners tranferred in 1852 was faked. ${ }^{37}$ In all she spent twenty-nine years in the Penitentiary, at least for some time employed as a servant to the governor. A succession of petitions, beginning in the late 1840s with one by influential gentlemen from Kingston (obviously orchestrated by her defence law yer), urged the case for her release. Regrettably, as no documentation has survived, the grounds for petitioning are unknown. By 1869 the now federal Ministry of Justice, declining to accede to yet another petition, noted on the file that the case 'has been frequently before the Government and fully considered. ${ }^{, 38}$ With some relief, one senses, the government pardoned her in the course of a general review of long-term prisoners in $1872 .^{39}$

\section{The Mirror, 10 Nov. 1843.}

36. On the melodramatic mode as characteristic of mid-nineteenth-century criminal tales, see Wiener, Reconstructing the Criminal, 21ff.; Susanna Moodie, Life in the Clearings (New York, 1853), chaps. X, XV.

37. OA, RG 10, Toronto Lunatic Asylum General Register. Grace Marks was admitted on 4 May 1852 and discharged 18 Aug. 1853.

38. NA, RG 13, Al, Department of Justice, Central Registry Files, T4322 (mfm) 1869 Index and Register: file \#1154, Grace Marks.

39. Canada, Sessional Papers, 1873, no. 75, 'Return of Pardons for 1872.' One hundred and twenty-nine inmates received pardons in the two-year period 1871-72. 
In the world of myth, time can stand still. Apparently, passing decades did not diminish public interest in the legendary 'girl murderess' which was Grace Marks's only known identity. Time and retelling enhanced her beauty but not her innocence. In 1885 the author of the imposing two-volume History of Toronto and County of York betrayed the more worldly, more discernibly chivalrous perspective of his generation in his lengthy retelling of the saga of the Kinnear murder. The jury in recommending mercy, he observed, made 'one of those kindly but mistaken impulses by which juries are apt to be swayed where good-looking women are concerned.' For his part, 'the only conceivable grounds' for mercy in the case of Grace Marks was her 'extreme youth'-after forty years, a rationale advanced in public for the first time. ${ }^{40}$

In 1858, James Fleming's 'youth' was his best defence in the face of a charge of murder. ${ }^{41} \mathrm{He}$ was not much past his seventeenth birthday that December when an early evening drink with youthful acquaintances resulted in a drunken scuffle outside the Commercial Saloon on Wellington Street and the death, by stabbing, of his companion Tom Maddigan (alias Riordan). The city had grown dramatically since Grace Marks had lived there; Irish immigration as a result of famine had been followed by unprecedented economic and institutional developmentand inflation-in the early 1850s. More recently the impact of an international economic recession had begun to take its toll. By the autumn of 1858 the city was mired in the depths of depression. Unemployment and destitution were so widespread that it was unremarkable that both James Fleming and his unlucky companion had just lost their jobs.

James Fleming had until recently appeared to be a model youth. Left in the charge of an uncle in County Galway after his mother's death and his father's emigration to Quebec, James joined his father in Toronto in the early 1850s and attended the Christian Brothers' school with great success. He had 'a frank open countenance, was smart and intelligent beyond boys of his years and "station in life", the Brothers reported. At fifteen he left school and trained as a telegraph operator, rising through the ranks of various firms to a position of responsibility in the Grand Trunk office at Union Station. For the past four months James had

40. History of Toronto and the County of York (Toronto: Blackett Robinson, 1885), I: chap. 4, 38. See also Carolyn Strange, 'Wounded Womanhood and Dead Men: Chivalry and the Trials of Clara Ford and Carrie Davies,' in Gender Conflicts: New Essays in Women's History, ed. Franca Iacovetta and Mariana Valverde (Toronto: University of Toronto Press, 1992), 149-88.

41. NA, RG 5, C1, Provincial Secretary, C.W.: numbered correspondence, vol. 604, file 245. Newspaper reporting was too extensive to itemize. In general, reports clustered around the dates of the coroner's inquest, 7-11 Dec. 1858; the opening of the winter Assizes, 11 Jan. 1859; the trial, 21 Jan.; the sentencing, 7 Feb., and pre- and post-execution, 2-5/7 Mar. 1859. Specialized and out-of-town comment tended to run as much as a week later. 
not lived with his elderly father, but boarded at the Young Canada Saloon downtown. That, it appears, was a great mistake.

From the morning after the fatal mishap, which occurred during the evening of 6 December, to well after his execution on 4 March 1859, James Fleming's case attracted unprecedented attention in the press. Toronto's most respectable newspapers-the Globe and The Leader-devoted columns to verbatim reports of the four days of the inquest; the trial in January; and the sentencing in February. In the three days running up to the execution the attention was on Fleming's life-story and gaol-cell confessions (there were two), and the extraordinary efforts which were being made on his behalf to secure the commutation of the death sentence. Much of this was reported, analyzed, and elaborated upon in newspapers across the province. ${ }^{42}$

A striking feature of all the words spoken and written about James and his companions is the imprecision of the vocabulary used to describe them. 'Youth,' 'lad,' 'boy,' 'young man'-even a seventeen- or eighteen-year-old could, and did, pass for any one of these, depending on his character, his class, and the level of social anxiety at the time. A number of different voices can be heard talking about James: his young Irish companions, female and male; the middle-aged parents of his victim and their neighbours amongst the Irish labourers of Stanley Street; the male employers of both Fleming and Riordan; the Coroner and his jury; crown and defence counsel; the trial jurymen and Mr. Justice McLean, who presided over the assizes; the many hundreds of prominent male citizens in Quebec, Montreal, Kingston, and Toronto, and the ninety-five Toronto matrons who petitioned the Executive on Fleming's behalf; the Rev. Mr. Marling, who gave a free public lecture at Temperance Hall following the execution on how he helped James to write his confessions; and, not least, the contradictory voices from editors' desks. In talking about James, they were all also describing and responding to a variant of masculine youth culture in which honest work was accompanied by late nights, drinking, easy-if not immoral-relations between the sexes, and a certain level of violence. ${ }^{43}$

42. My sampling of the local press across the province included The Sarnia Observer and Lambton Advertiser, which showed a keen interest in the case, copying the Toronto press at length in December, January, and March. Sarnia had a population of 2,000 persons at the time.

43. On the general point see Michael Roper and John Tosh, eds., Manful Assertions: Masculinities in Britain since 1800 (London: Routledge, 1991), esp. intro. 18; Anthony Rotundo, 'Learning about Manhood: Gender Ideals and the Middle-Class Family in Nineteenth-Century America,' in Manliness and Morality: Middle-Class Masculinity in Britain and America, 1800-1940, ed. J.A. Mangan and James Walvin (New York: St. Martin's Press, 1987), 35-51; Stansell, City of Women, 91-101, $185 f$. On the violence which flared occasionally amongst working-class youth in Toronto, see Barrie Dyster, 'Captain Bob and the Noble Ward,' in Forging a Consensus: Historical Essays on Toronto, ed. Victor L. Russell (Toronto: Univer- 
Why the extraordinary interest in this case? What fed the sentimentalism implied by the choice of nouns 'lad' and 'boy'? Why the virtually universal assumption (certainly shared by the petit jurors, as they had in Grace Marks's case) that Fleming would receive a reprieve, that his sentence would be commuted to life imprisonment in Kingston Penitentiary? Why did hundreds of the most prominent male citizens of the major cities in the Province of Canada, including members of the Grand Jury, the Coroner, and others intimately involved in the case, sign petitions pleading the extenuating circumstances of extreme youth, previous good character, the absence of malice and premeditation, and the unreliability of the witnesses? The most obvious - and undocumented - reason is that the petition-signing was orchestrated by Fleming's chief defence counsel, Henry Eccles, Q.C. In addition to having a highly arguable case that 'Intent' had not been adequately established, Eccles may have had a more personal, professional motive. He and the Crown prosecutor, the Hon. John Hillyard Cameron, had been sparring during the Assizes and the previous week Eccles had won a dubious acquittal in the case of a young male-in all likelihood much the same age as Fleming - accused of leading a 'youthful' gang raid on a brothel. ${ }^{44}$ Cameron proved a poor loser, and was pursuing lesser charges to gain a conviction. But beyond Eccles' interest lies the question as to why they all signed. In Fleming's case, the earnestness and persistence of his supporters' efforts suggest to the historian the complex emotional investment which many in this colonial community had made in the 'proper' education of youth and, through that, in an appropriately ordered society. James had so successfully fulfilled the promise and then lost it; hence, too, the necessity to draw a moral from the tale.

The decisive voice in this case was, of course, the government's. Ironically, in the end Fleming's 'youth' condemned him. A flagrantly masculine youth culture had taken hold in the city which appeared to threaten class boundaries. The government's response was framed in terms of the danger posed by the carrying of knives and other deadly weapons, which had become so prevalent that it was 'imperatively necessary that an example should be made.' Crafted by the Rev. Mr. Marling, James Fleming's scaffold statement echoed past criminal confessions in its depiction of a promising life ruined by novel-reading, theatregoing, the occasional indulgence in liquor, and the choice of bad company. In

sity of Toronto Press, 1984), 98-100, and Michael Cottrell, 'St. Patrick's Day Parades in Nineteenth-Century Toronto: A Study of Immigrant Adjustment and Elite Control,' Histoire sociale/Social History 49 (Mai-May 1992): 57-74.

44. There was no right of appeal on matters of law or fact in criminal cases in this period. See Martin L. Friedland, A Century of Criminal Justice: Perspectives on the Development of Canadian Law (Toronto: Carswell, 1984), 237; Globe, 15 and 21 Dec. 1858, 14 Jan. 1859; The Leader, 15 Dec. 1858, 14 Jan. 1859. Ellen Rogers, who owned the premises and was one of the victims of the 'outrage,' described the intruders as ' 16 or 17 of the boys.' For an analysis of the incident, see Backhouse, Petticoats \& Prejudice, 81-101. 
1859, many respectable citizens regarded these tendencies as rampant. The widely read Methodist Christian Guardian spoke to and for many of its readers as it condemned what it regarded as a specious notion of manhood by cataloguing the fateful distractions of the saloon, the theatre, and the dancing-room, which led on to gambling and the carrying of deadly weapons and 'into the fearful vortex of which Fleming has been drawn. 45

Taken literally, the 'role of the law' in the cases of the youthful killers Grace Marks and James Fleming might well be described as 'capricious.' But it is better if social historians, at least, not leave the 'law' at the level of its literal meaning, but probe, over time, the intersection of legal conventions, prevailing notions of criminality, and more widely shared anxieties about the normative social relations of age, class, and gender.

The 'end' of the stories of Grace and James may prove to be instructive. As far as one can tell, no one outside the justice system noticed Grace Marks's pardon in 1872. But in the mid-1880s she figured in a new genre of accounts of Toronto's demi-monde and scandalous past. Grace seemed never to fit into the classic Victorian madonna/whore dichotomy. Oddly enough, while her youth and attractiveness were relentlessly remarked upon during the trial, she remained insulated from sexual innuendo. The nature of her relations with her co-accused, James McDermott, were only a matter of speculation when it came to believing that she could possibly have been a reluctant, coerced partner in crime. The reasoning related to psychology, not sexuality. How enduring and limiting were prevailing notions of femininity is captured in the melodramatic fantasies of the mid-1880s which—on the basis of no evidence at all-depicted Grace, aged forty-five, on release from the penitentiary going to the United States, changing her name, marrying...and living happily ever after $?^{46}$ By the late $1880 \mathrm{~s}$, a new impulse to moral regulation would uncover, in precocious sexuality, the delinquency of young females in the city. But at mid-century young females, whatever the activities which brought them within the ambit of the law, were rarely 'seen' as individuals; nor did they constitute a youth problem to the same extent as young males. The preoccupation with character formation which had become a sub-text of the criminal justice system effectively precluded young females, as their futures held no promise of independent social, economic, or political identity...let alone influence.

45. 'A Terrible Warning,' Christian Guardian, 9 Mar., 1859; also 'The Murderer Fleming; a lecture by Mr. Marling,' Globe, 10 Mar. 1859; and the Charge to the Jury by Mr. Justice Hagarty at the opening of the Spring Assizes, Toronto, Globe, $10 \mathrm{Apr}$. 1860.

46. The Night Hawks of a Great City, as seen by the reports of 'The Toronto News' (Toronto, 1885), 30; History of Toronto and County of York, I: 48; Landmarks of Toronto, III: 260. 
By contrast, James Fleming's ordeal fuelled an ongoing discussion about the relationship between adult and juvenile crime as well as moralizing commentary on the fate of 'to-day's youth. ${ }^{47}$ In the spring of 1859 the government's decision to proceed with exemplary punishment in his case suggests a prevailing mood close to "moral panic. ${ }^{48}$ That mood would pass; but the equivocal figure which all the legal reportage had fashioned - of a promising male youth corrupted by a propensity for casual drinking, loose companions, and unprovoked violencehad been materialized and would return and be recognized in communities across the province in later decades and future recessions.

47. In 1857 the government had introduced legislation authorizing summary trials for juveniles (sixteen years and under, both sexes) and the establishment of two juvenile reformatories for prisoners under the age of twenty-one years (20 Vic. chs. 28 and 29 [1857]). Over the next decades, trial and error would quickly rid the reformatory experiment of responsibility for 'juvenile' females and a pioneering board of inspectors would struggle to fix, by administrative fiat, chronological milestones in the process of achieving manhood by creating an appropriate institutional analogue: boys' homes and industrial schools at the lower ages and a central reformatory prison at the other.

48. For a working definition of 'moral panic,' see Stuart Hall et al., Policing the Crisis: Mugging, the State, and Law and Order (London: Macmillan Education Ltd., 1978), 16; Augustine Brannigan, 'Moral Panics and Juvenile Delinquents in Britain and America,' Criminal Justice History 8 (1987): 181-92. 